\title{
PENGARUH MODEL PEMBELAJARAN 5E TERINTEGRASI PENDEKATAN SAINTIFIK TERHADAP KEMAMPUAN LITERASI SAINS SISWA SMPN 1 KURIPAN TAHUN AJARAN 2016/2017
}

\section{THE EFFECT OF THE 5E LEARNING MODEL INTEGRATED SCIENTIFIC APPROACH TOWARDS THE ABILITY OF SCIENCE LITERACY OF SMPN 1 KURIPAN STUDENTS AT 2016/2017 ACADEMIC YEARS}

\author{
Alok Irma Suryani ${ }^{1)}$, Jufri, A.W ${ }^{2}$, Dadi Setiadi ${ }^{3)}$ \\ ${ }^{1)}$ Mahasiswa Pendidikan Biologi FKIP Universitas Mataram \\ ${ }^{2) 3)}$ Dosen Pendidikan Biologi FKIP Universitas Mataram \\ Universitas Mataram, Jalan Majapahit No.62, Mataram, Indonesia \\ Email: Alokirma32@gmail.com
}

Received: 14 Februari 2017; Accepted: 28 Maret 2017

\begin{abstract}
Abstrak: Penelitian ini bertujuan untuk mengetahui pengaruh model pembelajaran 5E terintegrasi pendekatan saintifik kemampuan literasi sains berdasarkan kategori daya nalar siswa yaitu nominal, fungsional, konseptual/prosedural dan multidimensional. Penelitian ini tergolong eksperimen semu dengan pola Pre-Test dan Post-Test Group Design. Populasi penelitian yaitu seluruh siswa kelas IX SMPN 1 Kuripan tahun ajaran 2016/2017. Sampel kelas dipilih dengan teknik Purposive Sampling sehingga didapatkan kelas IX-A sebagai kelas eksperimen dan kelas IX-B sebagai kelas kontrol, dengan sampel berjumlah 50 siswa. Instrumen yang digunakan yaitu tes kemampuan literasi sains berupa soal uraian. Data kemampuan literasi sains dianalisis secara kualitatif dan dikatagorikan menjadi 4 yaitu katagori nominal, fungsional, konseptual/prosedural dan multidiminsional. Hasil penelitian menunjukkan bahwa kemampuan literasi sains siswa yang menerapkan model pembelajaran 5E terintegrasi pendekatan saintifik berada pada 4 kategori yaitu katagori nominal sebanyak 7,6\%, fungsional sebanyak 26,9, konceptual/prosedural sebanyak 53,8\% dan multidiminsional sebanyak $11,5 \%$ sedangkan pada kelas yang tidak menerapkan model pembelajaran 5E terintegrasi pendekatan saintifik berada pada 2 kategori yaitu katagori nominal sebanyak 70,8\% dan katagori fungsional sebanyak $29,1 \%$.
\end{abstract}

Kata-kata Kunci: 5E, pendekatan saintifik, kemampuan literasi sains

\begin{abstract}
The aim of this research is to know the effect of the 5E teaching model integrated scientific approach towards ability of science literacy based on category of nominal, functional, conceptual/procedural and multidimensional. This research is classified as quasi-experimental, with Pre-Test dan Post-Test Group Design. The population of this research were all the nine grade students of junior high school 1 Kuripan academic year 2016/2017. The class sample was taken by using purposive sampling in which IX-A became the experimental class and IX-B became the control class, with number of sample 50 students. The instruments that is used the data was ability of literacy science in form of essay. The date ability of literacy science was analyzed by using kualitative and was category became 4 on on category of nominal, functional, conceptual/procedural and multidimensional. The result of research showed the ability of literacy scince data showed that percentage of student implemetation the 5E teaching model integrated scientific approach in the nominal 0f 7,6\%, fungsional of $26,9 \%$, konceptual/prosedural of $53,8 \%$ dan multidiminsional of ,5\%, while the class not implemetation the $5 \mathrm{E}$ teaching model integrated scientific approach in the nominal category of $70,8 \%$ dan fungsional catagory of $29,1 \%$.
\end{abstract}

Keywords: 5E, scientific approach, ability of science literacy

\section{PENDAHULUAN}

Pada tahun 1997, OECD memunculkan Programme for International Student Assessment (PISA). PISA bertujuan untuk memetakan kemampuan literasi matematika, membaca dan sains siswa SMP yang berusia sekitar 15 tahun di negara-negara anggota OECD termasuk negara Indonesia. PISA mengumpulkan informasi yang reliabel setiap tiga tahun. Temuan-temuan PISA digunakan antara lain untuk: (a) membandingkan literasi membaca, matematika dan sains siswasiswa suatu negara dengan negara peserta lain; dan (b) memahami kekuatan dan kelemahan sistem pendidikan masing-masing negara [1].

Berdasarkan hasil tes PISA, kemampuan siswa Indonesia cenderung mengalami penurunan. Pada tahun pertama penyelenggaraan PISA Tahun 2000, Indonesia berada di urutan ke-38 dari 41 negara peserta pada kompetensi literasi sains [2], pada PISA periode kedua (2003), Indonesia juga berada pada urutan ke-38 untuk kompetensi literasi 
sains [3], dan pada PISA periode ketiga Tahun 2006, Indonesia berada pada urutan ke-53 dari 57 negara peserta [4], pada periode keempat Tahun 2009 menyatakan bahwa kompetensi literasi sains siswa Indonesia berada di peringkat ke-62 dari 65 negara peserta [5]. Hasil terbaru pada Tahun 2012 Indonesia berada pada urutan ke 64 dari 65 negara [6].

Data tentang rendahnya tingkat literasi sains dapat mencerminakan bahwa kualitas pembelajaran sains SMP di Indonesia masih jauh dibawah negara-negara OECD, sehingga sekolahsekolah di Indonesia perlu mempelajari bagaimana perencanaan, pelaksanaan dan penilaian pembelajaran sains, sehingga dalam beberapa tahun mendatang bisa lebih kompetitif antara hasil tes literasi sains siswa Indonesia dengan hasil tes siswa di negara-negara OECD. Kementerian Pendidikan dan Kebudayaan telah melakukan perubahanperubahan dalam bidang pendidikan salah satunya yakni penerapan kurikulum 2013. Tujuan mata pelajaran IPA yang tercantum dalam Permendikbud Nomor 58 tahun 2014 tentang Kurikulum 2013 Sekolah Menengah Pertama Dan Madrasah Tsanawiyah adalah: 1) Mengagumi keteraturan dan kompleksitas ciptaan Tuhan tentang aspek fisik dan materi, kehidupan dalam ekosistem, dan peranan manusia dalam lingkungan sehingga bertambah keimanannya, serta mewujudkannya dalam pengamalan ajaran agama yang dianutnya. 2) Menunjukkan perilaku ilmiah (memiliki rasa ingin tahu, objekti, jujur, teliti, cermat, tekun, hati-hati, bertanggung jawab, terbuka, kritis, kreatif, inovatif dan peduli lingkungan) dalam aktivitas sehari-hari sebagai wujud implementasi sikap dalam melakukan pengamatan, percobaan, dan berdiskusi.

Kenyaataan di sekolah, pembelajaran IPA masih terfokus pada dimensi konten. Menurut [8] bahwa pendidikan sains di Indonesia sekarang masih didominasi oleh pandangan bahwa pengetahuan sains hanya berupa seperangkat faktafakta yang harus dihafalkan oleh siswa. Dalam kondisi seperti ini, tentu pendidikan sains kita akan tertinggal dari negara-negara yang telah menerapkan kurikulum sesuai dengan tuntutan PISA. Pada implementasi kurikulum 2013, kegiatan pembelajaran IPA dikembangkan dengan pendekatan saintifik atau yang lebih dikenal dengan sebutan 5M (mengamati, menanya, mengumpulkan informasi, menalar, mengkomunikasikan).Proses pembelajaran dengan pendekatan saintifik tercantum di dalam Permendikbud Nomor 103 tahun 2014 tentang pembelajaran pada pendidikan dasar dan pendidikan menengah meliputi kegiatan mengamati, menanya, mencoba, menalar, dan mengkomunikasikan. Nasution (2013) menyatakan bahwa pendekatan saintifik atau yang bisa disebut dengan pendekatan ilmiah dipandang paling cocok dalam pengembangan sikap, keterampilan, dan pengetahuan siswa. Oleh karena itu, kondisi pembelajaran yang diharapkan dapat mendorong siswa dalam mencari tahu dari berbagai sumber dan bukan hanya diberi tahu.

Pendekatan saintifik diharapkan dapat mencapai tujuan-tujuan pembelajaran IPA dan meningkatkan literasi sains siswa. Literasi sains merupakan suatu hal yang sangat penting untuk dikuasai setiap individu karena hal ini berkaitan erat dengan bagaimana seseorang dapat memahami lingkungan hidup dan masalah-masalah lain yang dihadapi oleh masyarakat modern yang sangat bergantung pada perkembangan ilmu pengetahuan dan teknologi, termasuk juga masalah sosial kemasyarakatan. Ciri-ciri siswa yang memiliki literasi sains yang baik, yaitu siswa dapat mengidentifikasi isu-isu sains, menjelaskan fenomena sains dan menggunakan fakta atau bukti sains [5]. Dari pernyataan tersebut maka, guru diharapakan dapat menggunkana salah satu model pembelajaran yang interaktif, inovatif dan dapat membantu siswa dalam meningkatkan literasi sains. Salah satu inovasi model pembelajaran yang dapat digunakan adalah model pembelajaran 5E terintegrasi dengan pendekatan saintifik.

Menurut [10] model belajar 5E terdiri atas lima fase yang saling berhubungan satu sama lainnya, yaitu: engagement, exploration, explaination, elaboration, dan evaluation. Fasefase dalam model 5E memiliki fungsi khusus untuk mendukung tercapainya kompetensi yang harus dicapai dalam pembelajaran dengan cara berperan aktif. Selain itu fase-fase dalam 5E ini diintegrasikan dengan $5 \mathrm{M}$ pendekatan saintifik, sehingga siswa melakukan kegiatan menggali dan menemukan pengetahuannya sendiri melalui kegiatan pengamatan/praktikum, dengan siswa menggali dan menemukan sendiri pengetahuannya melalui pengalaman langsung dan nyata, pengetahuan yang didapatkan siswa tidak akan mudah dilupakan.

Model pembelajarn 5E merupakan model pembelajaran yang berlandaskan pada teori konstruktivistik. Teori konstruktivistik menekankan pentingnya siswa membangun sendiri pengetahuannya melalui keterlibatan langsung dalam proses mengajar, sehingga proses belajar mengajar lebih berpusat pada siswa. Menurut [11] keuntungan model pembelajaran $5 \mathrm{E}$ adalah pembelajaran akan bersifat student centered, berorientasi pada proses investigasi dan penemuan, pemecahan masalah, serta menghindarkan siswa dari cara belajar tradisional yang cenderung menghafal, sehingga dapat mendorong siswa menjadi aktif, kritis, dan kreatif. 
Berdasarkan pemaparan di atas peneliti tertarik untuk mengadakan penelitian yang berjudul "Pengaruh Model Pembelajaran 5E Terintegrasi Pendekatan Saintifik Terhadap Literasi Sains Siswa SMPN 1 Kuripan Tahun Ajaran 2016/2017”.

\section{METODE}

Jenis penelitian adalah penelitian Quasi experiment. Penelitian telah dilaksanakan pada semester genjil tahun ajaran 2016/2017 di SMPN 1 Kuripan pada siswa kelas IX di bulan Agustus sampai September. Variabel bebasnya adalah model pembelajaran $5 \mathrm{E}$ terintegrasi pendekatan saintifik, sedangkan variabel terikatnya adalah kemampuan literasi sains siswa. Populasi adalah seluruh kelas IX di SMPN 1 Kuripan tahun ajaran 2016/2017 yang terbagi dalam enam kelas, sampel ditentukan dengan teknik Purposive sampling dan diperoleh kelas IXA sebagai kelas eksperimen yang diajarkan dengan model pembelajaran 5E terintegrasi pendekatan saintifik dan kelas IXB sebagai kelas kontrol yang tidak diajarkan dengan model pembelajaran 5E terintegrasi pendekatan saintifik. Desain penelitian yaitu Pre-Test dan PostTest Group Design. Materi yang diajarkan dalam penelitian ini adalah sistem reproduksi pada manusia dan kependudukan dan lingkungan yaitu KD 3.1 dan 3.3.

Instrumen yang digunakan dalam pengumpulan data kemampuan literasi sains siswa menggunakan tes uraian sebanyak 4 soal yang sudah divalidasi oleh ahli.

\section{HASIL DAN PEMBAHASAN}

Kemampuan literasi sains kelas eksperimen mencapai katagori konseptual sebanyak $15,3 \%$, hal menunjukan bahwa sebagian siswa mampu menganalisis alternatif solusi terhadap permasalahan [12]. Selanjutnya katagori fungsional sebanyak $62,9 \%$ siswa dan katagori nominal sebanyak 4 siswa. Sedangkan untuk kelas kontrol hanya mencapai 2 katagori saja, yaitu katagori fungsional sebanyak $4,1 \%$ dan katagori nominal sebanyak 95,8\%. Hasil analisis pre-test kemampuan literasi sains terangkum dalam gambar 4.4

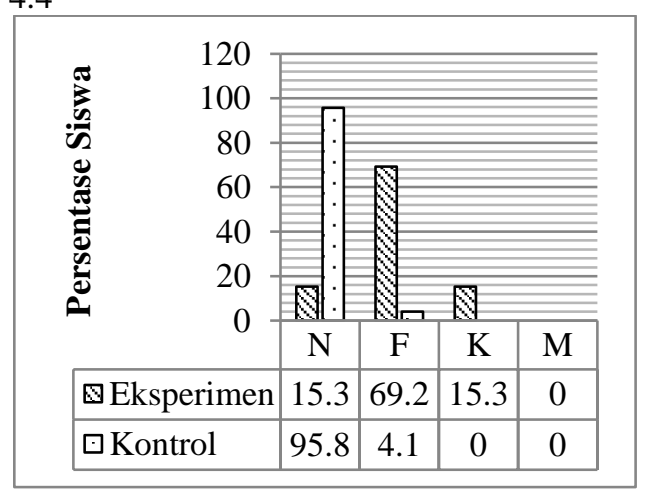

Gambar 4.4 Sebaran siswa berdasarkan kemampuan literasi sains sebelum perlakuan.
Sedangkan hasil analisis pos-test kemampuan literasi sains berdasarkan katagori jawaban siswa terangkum dalam gambar 4.5

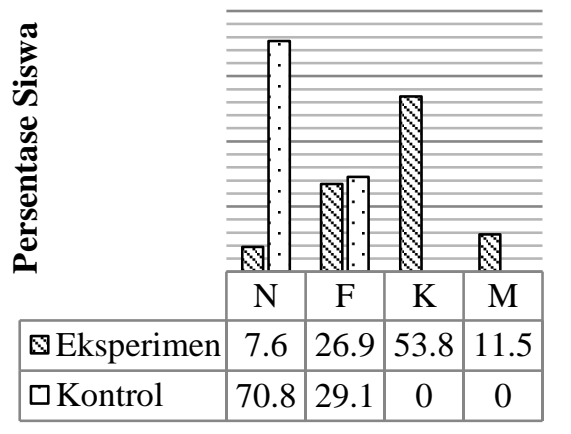

Gambar 4.5 Sebaran siswa berdasarkan kemampuan literasi sains setelah perlakuan

Kemampuan literasi sains siswa setelah perlakuan mampu mencapai katagori multidiminsional sebanyak 11,3\%, katagori konseptual sebanyak 53,8\%, katagori fungsional sebanyak 26,9\% dan katagori nominal sebanyak $7,6 \%$. Dengan tercapainya katagori multidiminsional, menunjukan bahwa Siswa memanfaatkan berbagai konsep dan menunjukkan kemampuan untuk menghubungkan konsep-konsep tersebut dengan kehidupan sehari-hari [12]. Sedangkan distribusi siswa yang tidak belajar dengan model pembelajaran $5 \mathrm{E}$ terintegrasi pendekatan saintifik hanya mencapai katagori fungsional sebanyak $29,1 \%$ dan katagori nominal sebanyak $70,8 \%$, hal yang menunjukkan bahwa siswa setuju dengan apa yang dinyatakan orang lain tanpa adanya ide-ide sendiri [12].

\section{Peranan Model Pembelajaran 5E Terintegrasi Pendekatan Saintifik Dalam Mengembang Kemampuan Literasi Sains}

Data dalam penelitian ini menunjukkan bahwa model pembelajaran 5E terintegriasi pendekatan saintifik berpengaruh meningkatan kemampuan literasi sains siswa. Literasi sains merupakan hubungan konsep-konsep sains yang diperoleh di sekolah kemudian diterapkan dalam kehidupan sehari-hari siswa. Peningkatan kemampuan literasi sains kelas eksperimen lebih tinggi dari peningkatan literasi sains pada kelas kontrol. Model pembelajaran 5E mampu meningkatkan kemampuan literasi sains siswa dikarenakan pada saat pembelajaran tatap muka guru menggunakan model 5E pada setiap kali pertemuan. Penggunaan model 5E membantu siswa untuk bertindak sebagai ilmuwan.

Kemampuan awal siswa kelas eksperimen menunjukkan beberapa siswa sudah berada pada katagori konseptual dan kelas kontrol menunjukkan bahwa siswa masih berada pada katagori nominal. Katagori nominal memiliki artinya siswa memiliki pemahaman tetapi pemahaman siswa masih 
tergolong miskonsepsi (Bybee, 1997). Sedangkan Setelah diterapkan model pembelajaran 5E terintegrasi pendekatan saintifik untuk kelas eksperimen sebagian besar siswa berada pada tingkat literasi multidimensional dan konseptual /prosedural. Tingkat literasi multidimensional merupakan tingkat literasi sains tertinggi dimana siswa mampu memberikan jawaban atas pertanyaan ilmiah dengan kemampuan analisis, sintesis, atau tingkat evaluasi sehingga jawaban siswa menunjukkan transformasi diluar yang disediakan buku teks, sedangkan tingkat konseptual merupakan tingkatan literasi dimana siswa mampu menghubungkan konsep sains dengan fenomena kehidupan sehari-hari [13].

Bentuk tertinggi dari suatu pemikiran siswa adalah penalaran [14]. Literasi sains merupakan pengambilan keputusan-keputusan yang bertumpu pada penalaran sesorang berdasarkan ilmu atau konsep yang dimiliki. Secara sederhana penalaran dapat didefinisikan sebagai proses pengambilan kesimpulan berdasarkan ilmu yang diperoleh ketika di sekolah. [14] menyatakan bahwa kemampuan bernalar dalam memahami konsep yang dimaksud adalah membandingkan antar konsep, mengaplikasikan konsep, dan menyimpulkan suatu konsep.

Data dalam penelitian ini juga menunjukkan bahwa terjadi peningkatan kemampuan literasi sains pada kelas kontrol. Kelas kontrol mengalami peningkatan kemampuan literasi sains, akan tetapi peningkatan kemampuan literasi kelas kontrol masih di bawah kelas eksperimen. Hal ini menunjukan bahwa siswa kelas kontrol belum memiliki kemampuan mengkomunikasikan konsepkonsep yang sudah dipahami. Sesuai dengan penelitian yang dilakukan [16], level ini yang biasanya dilatih dan dinilai pada ujian-ujian di sekolah. Persentase distribusi siswa kelas kontrol yang hanya mencapai 2 katgaori dari empat katagori menunjukan bahwa skor tes kemamapuan literasi sains berada pada katagori sedang dan rendah. Selain itu, disebabkan juga pada setiap pertemuan guru tidak menggunakan model pembelajaran 5E sehingga kemampuan literasi sains masih kurang maksimal.

Berdasarkan uraian diatas, terlihat betapa pentingnya memberikan pengalaman pada siswa agar mereka tidak hanya mengerti teori akan tetapi mendapatkan pengalaman langsung sehingga pelajaran yang didapatkan akan lebih melekat pada siswa. Salah satu alternatif yang bisa digunakan yakni menggunakan model pembelajaran $5 \mathrm{E}$ terintegrasi pendekatan saintifik.

\section{KESIMPULAN}

Berdasarkan hasil penelitian yang diperoleh, dapat disimpulkan bahwa: persentase kemampuan literasi sains siswa menunjukkan model pembelajaran 5E terintegrasi pendekatan saintifik dapat meningkatkan kemampuan literasi sains siswa. Kemampuan literasi sains siswa kelas eksperimen mencapai katagori multidimensional sebanyak $11,5 \%$ dan katagori konseptual/procedural sebanyak 53,8\%.

\section{DAFTAR PUSTAKA}

[1] Thomson, S. \& De Bortoli, L. 2008. Exploring scientific literacy: how Australia measures up the PISA 2006 survey of students' scientific, reading and mathematical literacy skills. Camberwell, Vic.: ACER Press.

[2] OECD. 2003. Literacy Science. Online. Tersedia: http://www.oecd.org/ dataoecd/38/29 /33707226. pdf. Akses tanggal 8 Agustus 2015.

3] OECD. 2004. Learning for Tomorrow's World. USA: OECD-PISA.

[4] OECD. 2006. Assessing Scientific, Reading and Mathematical Literacy, A Framework for PISA 2006. Paris: OECD Publications.

[5] OECD. 2009. PISA 2009 Assessment Framework, key competencies in reading, Mathematics and science. http://www.evaluacioneducativa/InformePISA 2009. pdf, diakses pada tanggal 16 September 2015.

[6] OECD. 2013. PISA 2012 Results. Diakses pada tanggal 8 Agustus 2015.

[7] Hernani dan Raharjo, M. 2009. Membelajarkan Konsep Sains-Kimia dari Perspektif Sosial untuk Meningkatkan Literasi Sains Siswa SMP. Dipublikasikan pada Jurnal Pengajaran MIPA.

[8] Permendikbud RI nomor 58 tahun 2014 tentang Kurikulum 2013 SMP Dan MTs. Salinan lampiran Peraturan Menteri Pendidikan dan Kebudayaan Republik Indonesia Nomor 58Tahun 2014

[9] Permendikbud RI Nomor 103 tahun 2014 tentang Pembelajaran pada Pendidikan Dasar dan Pendidikan Menengah. Salinan Lampiran Peraturan Menteri Pendidikan dan Kebudayaan Republik Indonesia Nomor 103 Tahun 2014

[10] Bybee, et al. 2006. The BSCS 5E Instructional Model: Origins and Effectiveness. Colorado: Office of Science Education National Institutesof Health.

[11] Agustyaningrum, N. 2011. Implementasi Model Pembelajaran Learning Cycle 5E Untuk Meningkatkan Kemampuan 
Komunikasi Matematis Siswa Kelas IX B SMP Negeri 2 Sleman. Seminar Nasional Matematika dan Pendidikan Matematika, Jurusan Pendidikan Matematika UNY, 3 Desember 2011, h. 6. [online] Tersedia:http://eprints.uny.ac.id/7389/1/p, diakses pada tanggal 30 September 2016.

[12] Odja, A. H dan Citron S. P. 2014. Analisis Kemampuan Awal Literasi Sains Siswa Pada Konsep IPA.Universitas Negeri Gorontalo. Prosiding Seminar Nasional Kimia, ISBN: 978-602-0951-00-3. Jurusan Kimia P-MIPA Universitas Negeri Gorontalo, 20 September 2014.

[13] Shofiyah, N. 2015. Deskripsi Literasi Sains Awal Mahasiswa Pendidikan Ipa.
Universitas Muhammadiyah Sidoarjo.

Journal Pedagogia ISSN $2089 \quad-3833$

Volume. 4, No. 2, Agustus 2015.

[14] Bybee. 1997. The Concept of Literacy: A View of the Current Debate as on Outgrowth of the Past Two Centuries. Electronic Journal of Literacy Through Science. Volume 1 Issue 1.

[15] Kusairi, S. 2012. Implementasi Blended Learning. Malang: Program Studi Pendidikan Fisika FMIPA UM.

[16] Shofiyah, N. 2015. Deskripsi Literasi Sains Awal Mahasiswa Pendidikan Ipa. Universitas Muhammadiyah Sidoarjo. Journal Pedagogia ISSN 2089 -3833 Volume. 4, No. 2, Agustus. 